\title{
集合住宅の居住者反応からみた 重量床衝撃音遮断性能の生活実感による表現方法の検討 EXPRESSION OF RESIDENT AWARENESS FOR FLOOR IMPACT SOUND BY HEAVY-IMPACT SOURCE IN MULTI-FAMILY HOUSING
}

\author{
井上勝夫*，阿部今日子**
}

Katsuo INOUE and Kyoko ABE

\begin{abstract}
We performed questionnaire survey of the resident awareness about the sound environment for the resident of multi-family housing. We obtained 784 valid response numbers of questionnaires votes. We analyzed the questionnaire survey from various angles. As a result, we obtained the following conclusion. (1)For the floor impact sound by heavy impact source, an evaluation method by the L-class is resident awareness to support well. (2) Resident judgment concerning of degree you hear - degree anxious - degree of noisiness - degree of problem consciousness degree of satisfaction were shown. (3) For the expression method of the actual feeling on living, it should use the plural items in cluding "degree to hear" and "the indication rate"
\end{abstract}

Keywords : Multi-family housing ,Sound environment performance, Resident awareness, Questionnaire survey 集合住宅, 音環境, 居住者意識, アンケート調査

\section{1.はじめに}

1979 年に刊行された日本建築学会編「建築物の遮音性能基準と設 計指針」1)は1997 年の見直しを経て、わが国の建築物の遮音性能の 向上及び、建築物の音環境に対する意識の向上に大きな役割を果た してきた。その中でも、遮音性能と生活実感の対応表現について は、技術者だけでなく消費者にも広く普及してきている。近年では 裁判時の判断資料として用いられたり、住宅購入前の消費者への説 明資料としてパンフレット等に引用される2) など多方面で利用され ており重要な役割を果たしている。

一方、2009 年には消費者庁が設立され、2000 年にスタートした 『住宅の品質確保の促進等に関する法律』が国土交通省と消費者庁 の共管となるなど、これまで以上に消費者の視点が重要視される時 代を迎えており、本来あるべき消費者を中心とする社会的背景は強 くなっている。よって、技術者だけでなく消費者にもわかりやす く、受け入れやすい生活実感に基づく性能表現をさらに充実させて 行く必要がある。

生活実感としての性能表現を検討寸るためには消費者の意見を正 確に抽出することが特に必要であるが、これまでの研究例では実験 室実験による「聞こえる程度」などの評価から類推するものが多く、 直接、居住者反応に基づいたものはほとんどない。本来、生活実感
としての性能表現は、長期に渡って居住する居住者の主観的判断結 果に基づく反応を平均化して行うべきものであり、居住者 (消費者) が判りやすい、理解しやすい生活にマッチした言葉で表現する方法 を導入すべきである。

また、この生活実感による性能表現は、消費者以外にも利用され るので、いろいろな場面で使用される事を想定しておくべきもので あることから、客観的立場にある大学や研究機関、学会等が中心と なってまとめて社会発信す心゙きものであり、業界や消費者など片 寄った立場から提案すべきものではないであろう。

筆者らのグループは、これまで集合住宅の音環境に対する居住者 の生活実感に関する研究として、1980 年前後 ${ }^{3) 4)}$ と 1995 年前後5) 8)、 2005 年前後 2) 9) 10) の大きく 3 期に渡って調査研究を行い、社会的に貴 重なデータを提示してきている。

1980 年前後では集合住宅における生活騒音の実態について、1995 年前後では居住者意識の構造や住まい方について、2005 年前後では

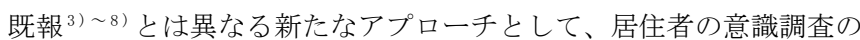
みに着目寸るのではなく、住宅購入前の消費者要求や供給者の説明 状況 2)9110) を含め系統的な研究を展開してきている。

本論文は、現在普及している日本建築学会の「表示尺度と住宅に おける生活実感との対応の例」11) と居住者反応の対応について検討を
** 日本大学理工学部建築学科 教授 $\cdot$ 工博

** 元 日本 ERI (株) 博士(工学)
Prof., Dept. of Architecture, College of Science and Technology, Nihon Univ., Dr. Eng. Former JAPAN ERI CO., LTD., Dr. Eng. 
行うと共に、集合住宅の音環境性能の中で最も重要視されて
いる重量床衝撃音を取り上げ、居住者反応調查結果を基に居 住者反応からみた重量床衝撃音遮断性能の生活実感による表 現方法の更なる検討を行ったものである。

\section{2. 調査概要}

アンケート実施物件概要を図 1 に示す。調査対象物件は、 建築着工統計調査 (国土交通省) ${ }^{12)}$ より分譲マンションの着工 新設住宅戸数が首都圈 (東京、神奈川、埼玉、千葉) に約半数「 集中していることを参考とし、図 1 に示寸 1 都 3 県 31 物件を 調査対象として選定した。有効票数は784 票である。

調査項目を図 2 に示寸。図 2 の下階住戸の生活実感 (B) に影
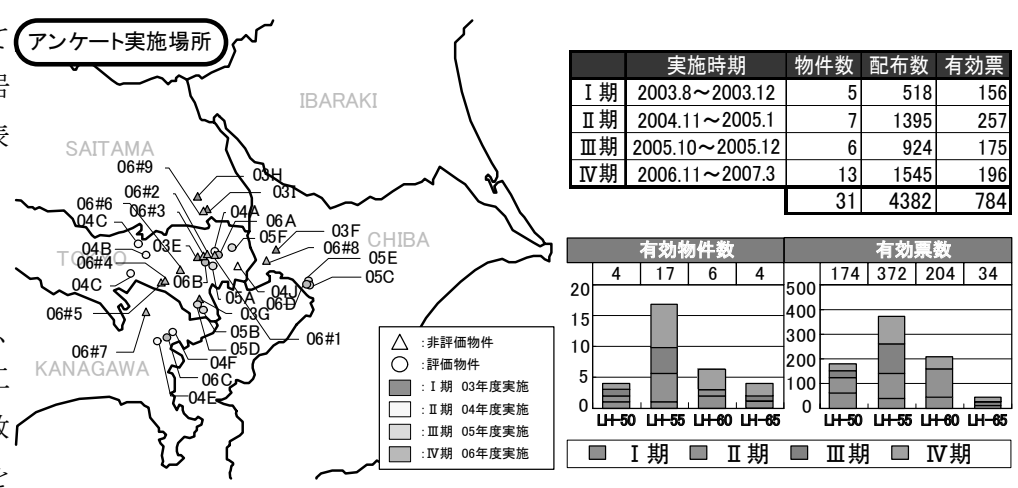

響を与えると考えられる、上階住戸に関する事 $(\mathrm{A}-1)$ から居住 者住戸に関する事 $(\mathrm{A}-3)$ までの各詳細項目について調査を行っ た。本論文では、その中から重量床衝撃音遮断性能 $(A-2)$ と下 階住戸の生活実感 (B ) の関係、上階住戸の家族構成・子供の 有無 $(A-1-1)$ と下階住戸の生活実感 $(B)$ との関係について検討 することとした。

具体的には下階住戸の生活実感 (B) として、「聞こえる音の種 類」、聞こえる程度」、「気になる程度」、「うるさい程度」、問題 意識の程度」「重量床衝撃音に対する満足度」、「表示尺度と住 宅における生活実感との対応の例』11)に示されている重量床 衝撃音に対する表現」、上階の気配の程度」について考察した。

また、アンケートを実施した建物の床衝撃音遮断性能の特 定は、実際の住戸を対象とした床衝撃音遮断性能の測定とイ ンピーダンス法による予測を併用して行った。重量床衝撃音 の測定は、JIS A 1418-2 「建築物の床衝撃音遮断性能の測定 方法一第 2 部 : 標準重量衝撃源による方法」に準拠して行なっ た。インピーダンス法による予測は、筆者らの提案する方法上階からの足音 13)により行った。

なお、本論文において示す「LH 值」とは、重量床衝撃音遮断子 性能の L 曲線による評価値の呼称である。J I S においては L r で表記されているが、本論文ではわかりやすく区別するため にLHと表記した。

\section{3. 調査・分析結果}

\section{$3-1$. 聞こえる音の種類と程度}

重量床衝撃音遮断性能別に「聞こえる音の種類」の指摘率を 図 3 に示す。階からの足音」、子供の飛び跳ね・走り回る 音」、物の落下音」、家具の移動音」等の床衝撃音は、性能が上 がるごとに聞こえる割合が低下しており、建築性能が聞こえ 方にはっきり表れている様子が伺える。

\section{3-2. 性能別の生活実感}

上階で発生する重量床衝撃系騒音に対する聞こえる程度を 重量床衝撃音遮断性能別にまとめた結果を図 4 に示す。同様 に「気になる程度」の集計結果を図 5 に、「うるささの程度」を図 6 に、「問題意識の程度」を図 7 に、満足度の程度」を図 8 に示 す。これらをみると、聞こえる程度 (図 4) は、性能が上がる ごとに指摘が聞こえない側に移行しており、図 5 から図 8 についてもその傾向がみられ、全体的に L 等級によるラン

図 1 アンケート実施物件概要

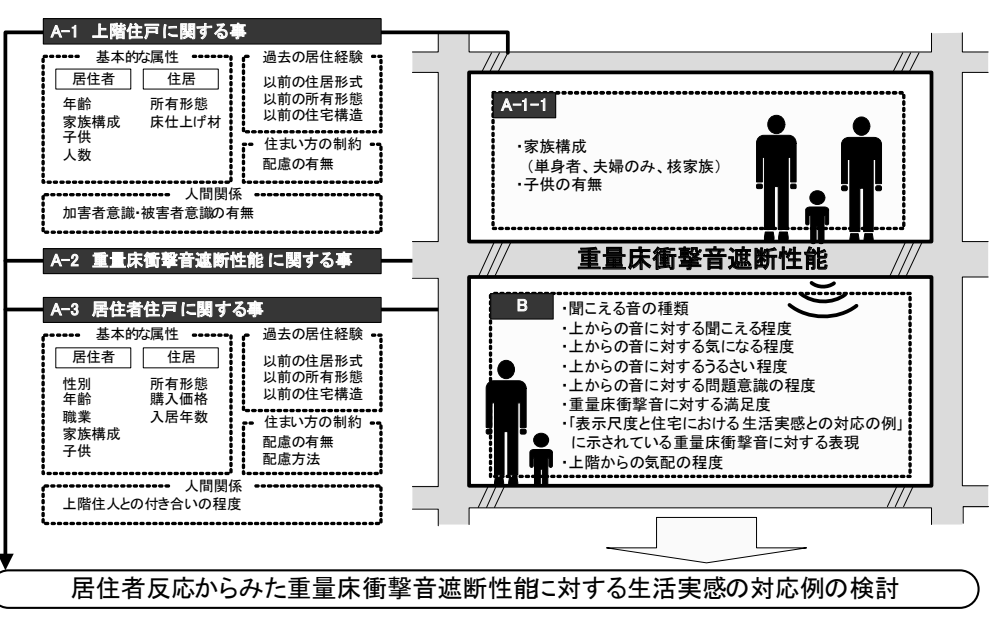

図 2 調查項目

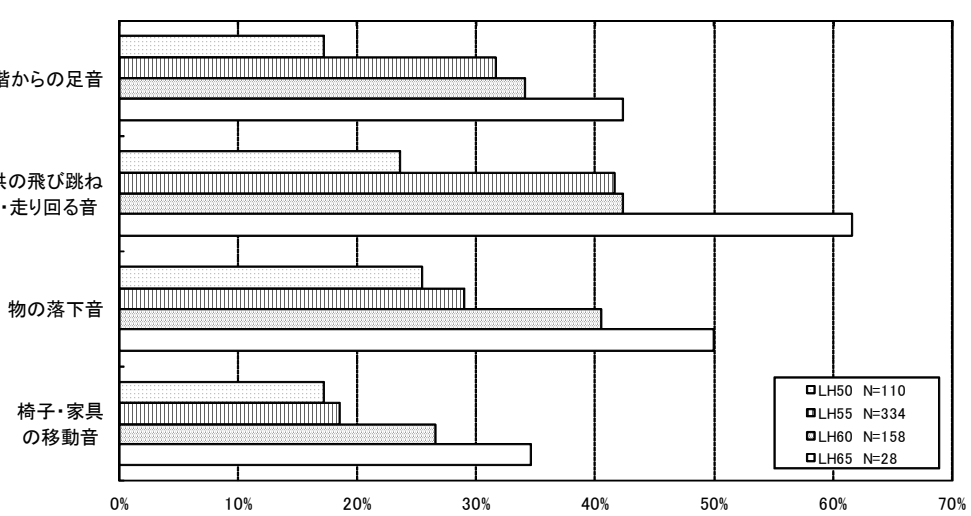

図 3 聞こえる音の種類と指摘率 (性能別)

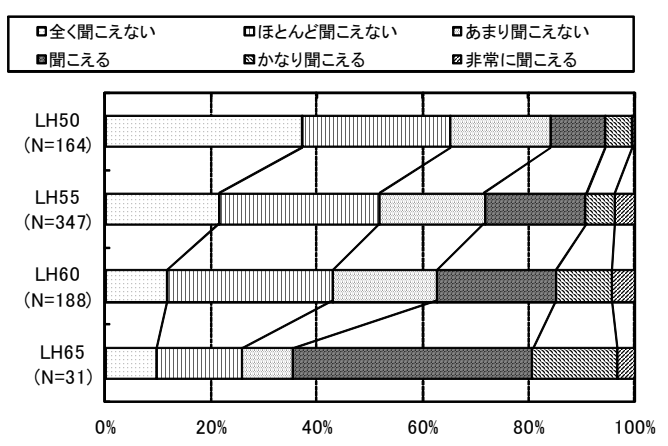

図 4 聞こえる程度の指摘率（性能別） 
クと居住者評価が良く対応している。図4 のLH50 においては、「全く 聞こえない、「ほとんど聞こえない、「あまり聞こえないを合わせる と 8 割以上を示しており、図 7 に示寸問題意識の程度をみても、問 題意識が低い様子がわかる。また、図 8 に示寸満足度をみてもほぼ 満足している様子が伺えることから、LH50 は居住者要求に応えられ る性能であると推察される。

図 5 をみると「気になる」とする指摘は、図 4 の「聞こえる」指摘に 比べ $10 \%$ 程度低くなっており、聞こえるとする意識から気になると する意識を推定することができるものと推察される。なお、聞こえ る指摘を性能で 1 ランク下げて考えると、気になる指摘率と同程度 ともみることができる。図 6 の「うるささの程度」は図 5 の「気になる」 指摘率の 1 ランク上の指摘率と同程度である。よって 1 ランクの差 が「うるささ」と「気になる」の感覚変化とみることができよう。

また、図 4 の「聞こえる(聞こえる十かなり聞こえる十非常に 聞こえる)」は図 8 に示す「満足度 (多少不満がある十非常に不満が ある)」の指摘率と同程度を示しており、満足度は「聞こえる程度」に 影響されるものと推察される。

さらに、図 5 の「気になる (気になる十かなり気になる十非常に気 になる)」指摘は図 7 の「問題意識 (やや問題がある十問題がある十か なり問題がある)」の指摘率と同程度を示しており、問題意識をもつ 判断基準は「気になる」とする判断に基づくことも推察される。「問題 がある」とする判断は訴訟事件等への発展が心配されるので、この評 価軸は非常に大事である。

以上の結果から L H によるランクは居住者反応 (長期に渡る生活実 感）としてみる性能変化を非常によくあらわしているといえる。ただ し、これらの居住者反応は図 1 の調査対象において、上階の居 住者の家族構成として子供の存在率が $12 \%$ 程度であることを明 記しておく。

次に、「気配を感じる」程度を判断基準とした反応を図 9 に示す。 これをみると、累積で $80 \%$ 程度の人の反応をみると、LH50 で「気配 を感じることがある」、LH55 で「気配を感じる」、LH60「在宅の有無が わかる」、LH65「生活行為がある程度わかる」という表現に対応してい る。一方、同じ気配を感じる程度について別の角度からみたグラフ 図 10 をみると、「気配を全く感じないりとす指摘率はLH50 からLH60 にかけて減少し、LH60 からLH65 では「気配を感じないり「気配を感 じることがある」が減少している。また、在宅の有無がわかる」から 「生活行為が大変よくわかる」までは性能ごとに徐々に増加しており、 言葉ごとに反応変化が異なっている。

図 4 から図 10 に共通する傾向として、「全く〜ない」という表現は 性能ごとに変化しているが、「ほとんど〜ない」、あまり〜ない」の中 間を意味する表現は性能別にあまり 差がないことがわかる。逆に「聞こえ る」「かなり聞こえる」「非常に聞こえ る」などの表現は性能ごとに多少変化 している様子が伺える。このことか ら、「全く聞こえない」「ほとんど聞こ えない」あまり聞こえない」な゙の聞 えない側の程度を表すよりも、聞こ える側の程度で表現したほうが性能 別の違いを居住者に理解してもら

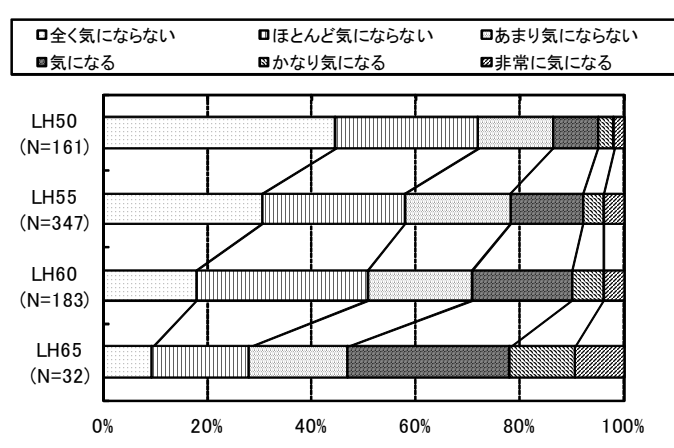

図 5 気になる程度の指摘率 (性能別)

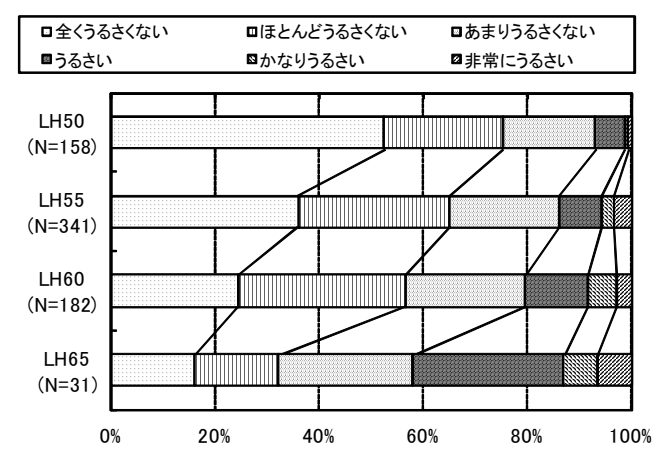

図 6 うるさい程度の指摘率（性能別）

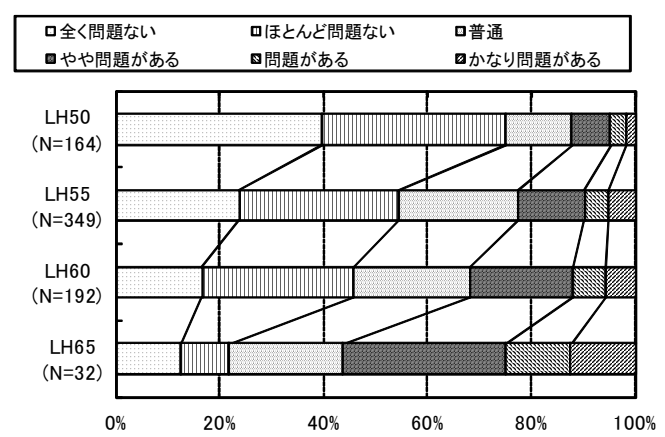

図 7 問題意識の程度の指摘率（性能別）

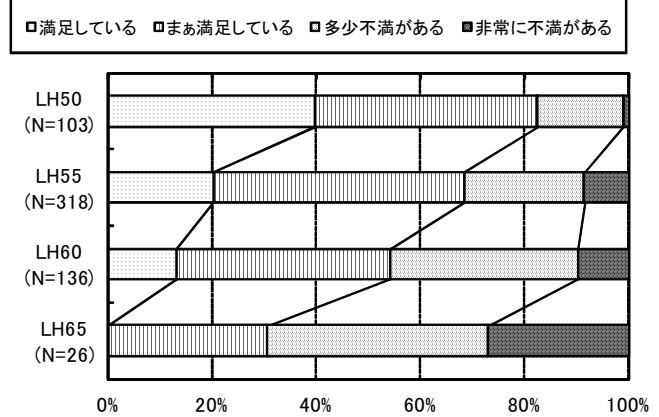

図 8 満足度の程度の指摘率 ( 性能別)

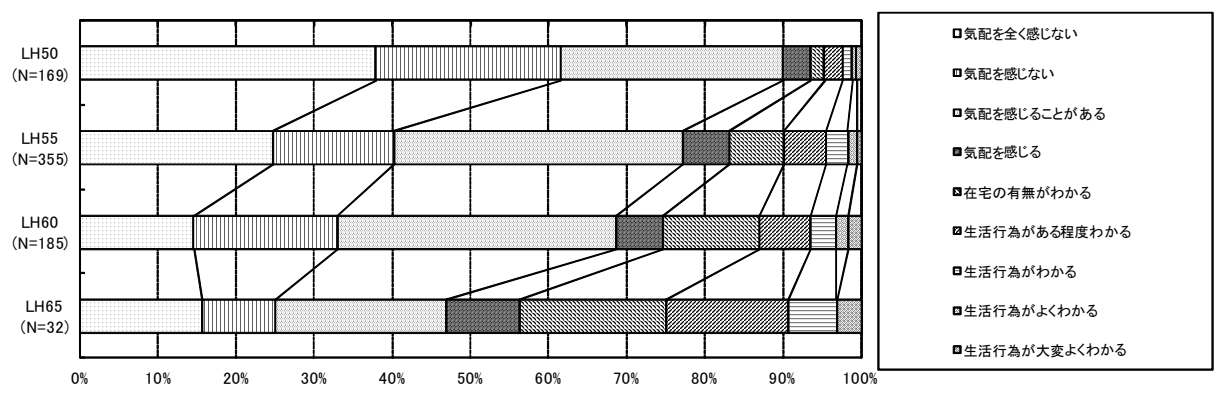

図 9 気配を感じる程度の指摘率（性能別_ 1 ) 
う意味では効果的であるとも 考えられる。ただし、これは性 能が LH50 〜 LH60 の範囲での傾向 であることから、性能が低い LH6 0 以下の場合についてはさら に検討が必要である。

次に、日本建築学会の重量床 衝撃音遮断性能に対する生活実 感としての表現内容 $\left.{ }^{11}\right)$ を直接居 住者に提示し、回答結果を LH ご とにまとめた結果を図 11 に示 す。これをみると、LH-50から LH-65 と性能が悪くなるごとに聞 こえる・うるさい側に反応が等 級変化に沿ってきれいに移行し ている。学会基準の表現と比較 してみると、LH50では、「LH50の 学会表現: 小さく聞こえる」まで の累積で $85 \%$ を超えており、現在 の学会基準の表現よりも悪く感 じている人は $15 \%$ 程度に留まっている。同様にLH55 で 89\%、LH60 で 87\%、LH65 で $85 \%$ となっており、長期間居住した場合の生活実感と して、現状の学会表現は $90 \%$ 程度の居住者反応に対応している といえる。なお、どの性能でも「かすかに聞こえるが、遠くから聞 こえる感じ」という表現は選択の割合が少なく、居住者の実感とし ては表現方法として使われにくい、あるいはなじみにくい表現であ ると考えられる。

以上の結果を踏まえると、生活実感として性能を表現する場合、 最多の文言を用いるのか、累積の值で検討するのか、性能別に明確 に差のある言葉を用いて表すのか、指摘比率により表示していくの か、これらの居住者反応をどのような形で表示していくことが望ま しいのかは、さらに検討の余地が残されるが、累積で $85 \%$ 程度と する表現を用いることも一つの目安と考えられる。

\section{3-3. 上階住戸の家族構成 - 子供の有無別による生活実感}

上階住戸が下階住戸の生活に与える影響を生活実感として表現寸 る方法を検討するため、上階の家族構成や子供の有無に着目して検 討を行った。

まず、上階の家族構成による聞こえ方の差をみるために、重量床 衝撃音遮断性能を固定して分析を行った。LH 55 の性能を有する住戸 を対象とした場合の調查結果を図 12 ～図 16 に示寸。図 12 より、上 階が単身者や夫婦のみでは「全く聞こえない」、「ほとんど聞こえな い」「あまり聞こえない」を併せると $80 \%$ 以上を示しているのに対し て、上階が核家族の場合は $50 \%$ 程度にとどまっており、聞こえる側 の指摘が高くなっている。同様に、図 13 から図 16 においても、上 階の家族構成が単身者 $\rightarrow$ 夫婦 $\rightarrow$ 核家族と順に下階住戸での生活実感 に差がみられるとともに、図 4 から図 8 と同様、聞こえる程度は満 足度と良い対応を示し、気になる程度は問題意識と同様な反応を示 寸結果となっている。図 17 に「表示尺度と住宅における生活実感と の対応の例」11)の表現内容 (項目)に対する集計結果を示すが、上階住 戸の家族構成によって、聞こえ方に大きな差が表れている。この学

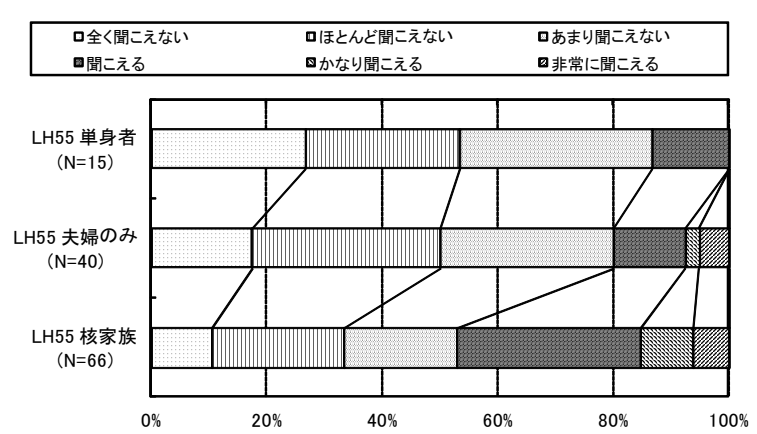

図 12 聞こえる程度の指摘率（上階家族構成別）

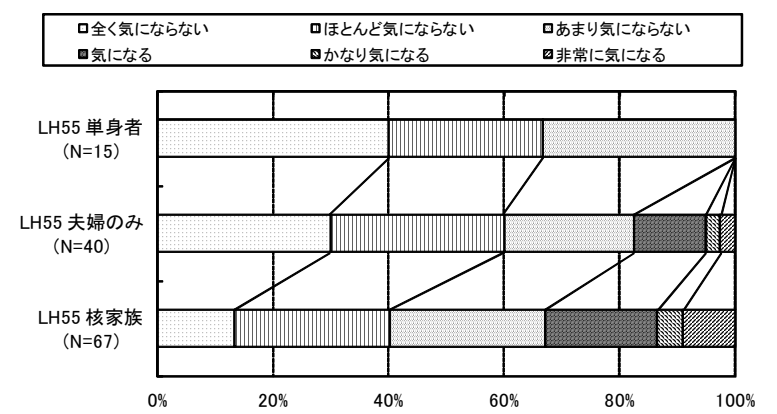

図 13 気になる程度の指摘率 (上階家族構成別)

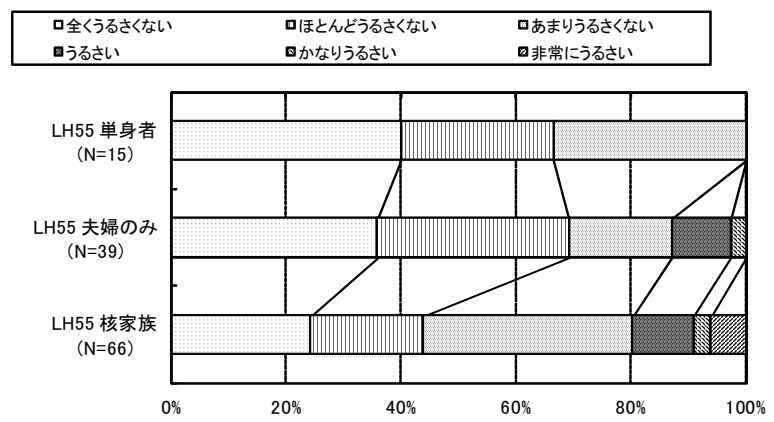

図 14 うるさい程度の指摘率 （上階家族構成別） 
会の実感表現は具体的な家族構成などが示されていない状態で運用 されていることから、上階に住む家族構成によっては居住後のトラ ブルを招く可能性が懸念される。尚、この傾向はLH50、60 でも同様 に示されている。

核家族の家族構成をみると子供がいることが多い事から、上階の 子供の有無が 1 つのポイントであると考えられる。そこで、聞こえ る音として最も指摘の高い10) 子供の音について、上階住戸の子供の 有無別に分析を行なった。なお、本論文では 12 歳以下 (小学生)を子 供と扱い分析を進めることとした。

図 18 の「階に子供がいない場合」の聞こえる程度の集計結果をみ ると、性能の低下と共に聞こえる率が高くなっていることがわか る。一方、図 19 の「上階に子供がいる場合」の結果をみると、子供が いない場合に比べて聞こえる程度の指摘が上がっている事がわか る。そこで、聞こえる」「かなり聞こえる」「非常に聞こえる」を合計し た結果を図 20 に示す。これをみると、LH50 では子供の有無による大 きな差は見られないが、LH55 $\rightarrow$ LH60 $\rightarrow$ LH65 と性能が低くなるにつれ て、子供の有無による差が大きくなっていることがわかる。これま で、上階に子供が居住した際に、下階の生活実感は 2 ランク程度低 いほうに移行するとの一般的な見解もみられたが、一律で 2 ランク 程度移行するのではなく、性 能によってその差が異なる事 が示されている。つまり、性 能が高くなれば上階の子供の 有無による聞こえ方の差は小 さくなるが、性能が低くなれ ばその差が大きくなることを 示していると言える。この傾 向は、気になる、うるさいで
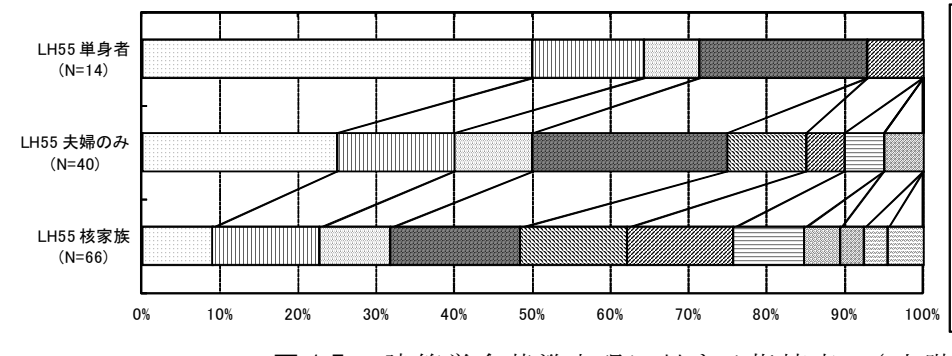

も示されている。ただし、こ

の結果は室内暗騒音が $35 \sim 40 \mathrm{dBA}$ 程度の空間における調查結果であ り、これが適用条件である。

同様に、問題意識の程度 (図 21 、図 22) の集計結果をみると、「や や問題がある」問題がある」「かなり問題がある」の指摘は、LH50 では 上階の子供の有無にかかわらず、問題意識を感じる割合は $10 \%$ 程度 と低く、上階の家族構成に左右されずに同様な空間性能を確保でき るレベルであるといえるが、性能別に「やや問題がある」「問題があ る」「かなり問題がある」の指摘を合計した図 23 の結果をみると、上 階に子供がいる場合、LH55 では 40\% 程度、LH60 では約 50\% 程度の人

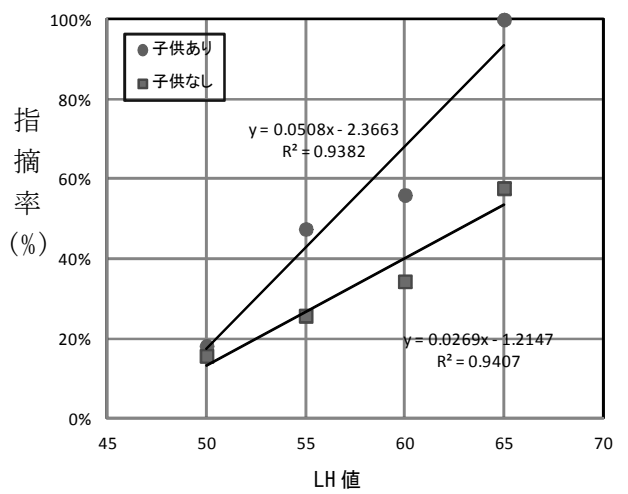

図 20 聞こえる程度の指摘率 : 上階子供の有無別 ( 性能別)
ロ全〈問題ない ロほとんど問題ない ロ普通 凹やや問題がある 日問題がある ロかなり問題がある

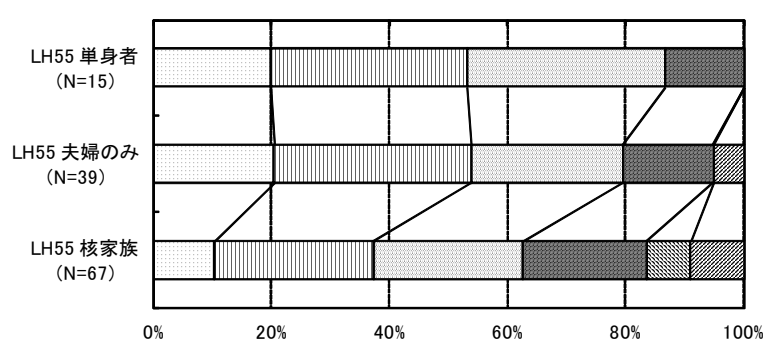

図 15 問題意識の程度の指摘率（上階家族構成別）

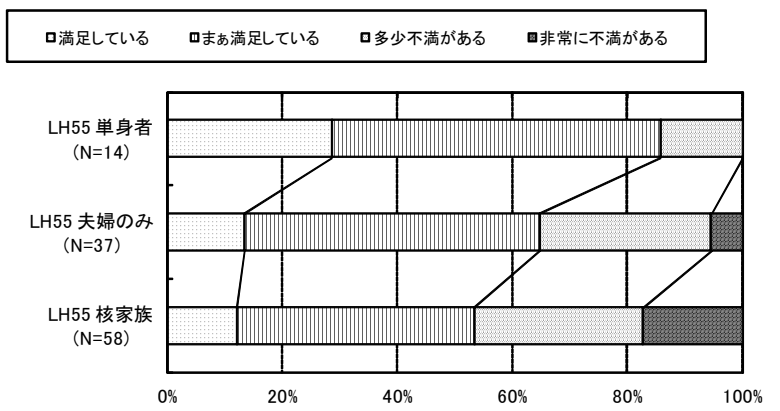

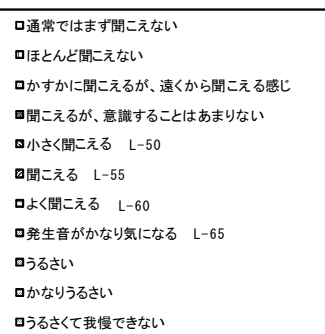

ロうるさくて我慢できない

図 17 建築学会基準表現に対する指摘率（上階家族構成別）

\begin{tabular}{|lll|}
\hline $\begin{array}{l}\text { 口全く聞こえない } \\
\text { 聞こえる }\end{array}$ & $\begin{array}{l}\text { 口ほとんど聞こえない } \\
\text { ロかなり聞こえる }\end{array}$ & $\begin{array}{l}\text { ロあまり聞こえない } \\
\text { ロ非常に聞こえる }\end{array}$ \\
\hline
\end{tabular}

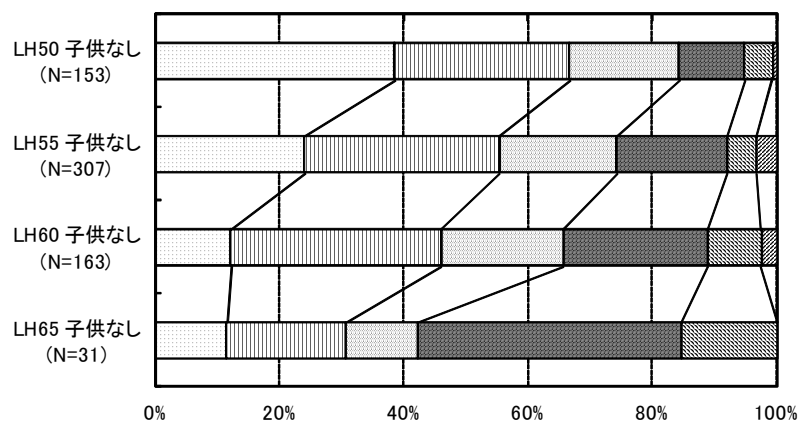

図 18 聞こえる程度の指摘率：上階子供なし( 性能別)

\begin{tabular}{|lll|}
\hline 口全〈聞こえない \\
四聞こえる
\end{tabular}

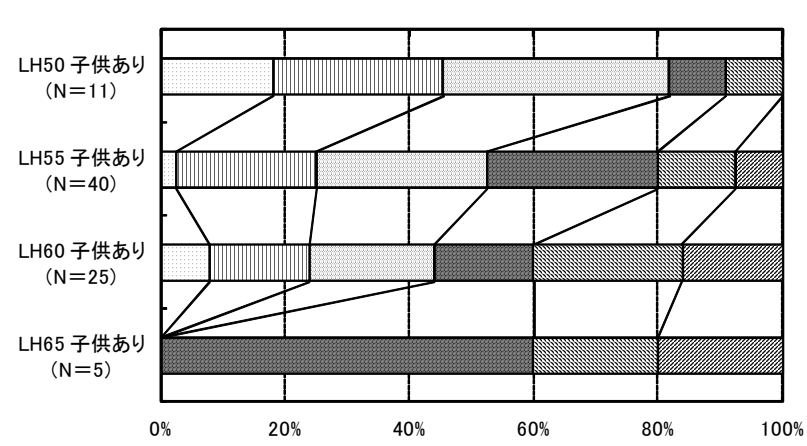

図 19 聞こえる程度の指摘率：上階子供あり（性能別） 
が問題意識を感じている様子が伺える。さらに、LH65 では、約 $80 \%$ の人が問題意識を感じており、LH6 5 の性能では子供に関する音の卜 ラブル発生率が高い状況にあることが明確である。日本建築学会 ${ }^{11}$ では、LH45を特級、LH50 を 1 級、LH55 を 2 級、LH60 3 級と位置け ており、RC 系の集合住宅では最低でも学会等級 3 級の LH60 を確保す ることが推奨されている。この基準は図 7 をみると妥当な性能を示 しているものと考えられる。また、LH50 が確保されていれば、音の トラブルは減少するものと思われることから、学会の 1 級に相当す る LH5 0 が建築技術の目指す心゙き 1 つ目標值であるとも考えられる。 ただし、前述のように住戸内の暗騒音レベルによる条件がかかるこ とを記しておく。

同様に学会の「表示尺度と住宅における生活実感との対応の例」 ${ }^{111}$ による集計結果を図 24 、図 25 に示寸が、図 24 の「上階に子供がいな い場合」は、どの性能においても現在の学会の表現よりも悪く感じて いる人は $10 \%$ 程度に留まっていることがわかる。しかし、図 25 の 「上階に子供がいる場合」をみると、LH50 では $90 \%$ 以上の人が学会基 準よりも聞こえない側の表現を指摘しており問題ないと考えられる が、LH55、LH60、LH65 と性能が低くなるにつれて、学会基準よりも 悪い側の指摘が増してきており、LH65 においてはその割合が約 $40 \%$ にまで達している。今回のデータでは上階に子供がいる場合の票数 が少ないものの図 2 で示した他の項目ではこのような差は見られな いことから、このデータは参考に值するものと考えられる。

\section{3-4. 重量床衝撃音遮断性能に対する生活実感の対応例}

本項では、本研究で明らかになった結果を踏まえて、表 1 に示す 「重量床衝撃音遮断性能に対する生活実感の対応例」を提案する。

検討に当って、集合住宅に居住する人々が通常の生活を行ってい る状態で、どのような反応を示し、どのような表現によって遮音性 能を説明するのか、言い換えればどのような表現方法・説明を行え ば人々が生活実感として重量床衝撃音遮断性能を理解できるのか、 と言う点を重要視した。本研究では、現在社会で広く利用されてい る学会提案の「表示尺度と住宅における生活実感との対応の例」11) が 多くの居住者に受け入れられていることから、それをべースに以下 の 3 点について再検討した。

1) 表現の一部見直し：直接的表 現として、居住者は音環境を 「聞こえる」、気になる」、「うるさ い」をべースとした一般的な言

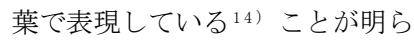
かになったことにより、現状の 学会表現は妥当な表現方法であ ると判断し、それに倣うことと した。ただし、現在の表現は整 理し、聞こえる程度と気配を感 じる程度を分けて示すこととし た。また、用いる表現は図 11 の累積で $85 \%$ 程度の表現とす ることとした。

2) 聞こえる率の表示 : 音源別に 居住者が聞こえる音として指摘 する割合をパーセンテージで示

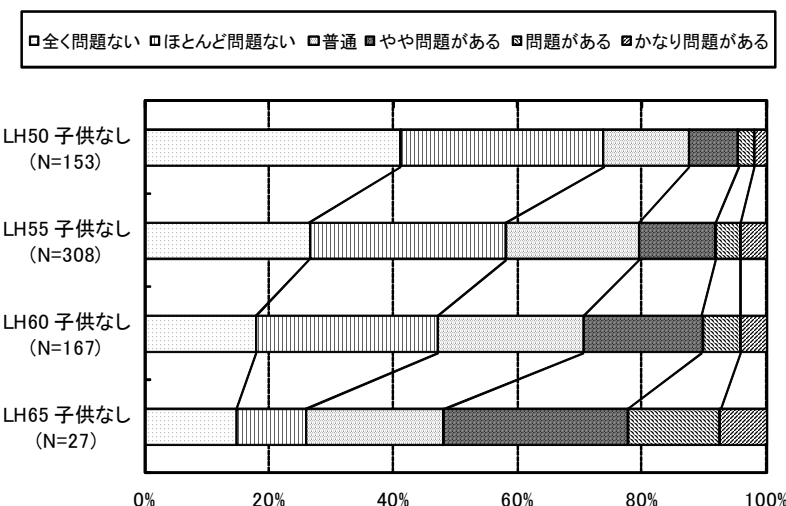

図 21 問題意識の程度の指摘率：上階子供なし( 性能別)

ロ全く問題ない ロほとんど問題ない ロ普通 ロやや問題がある 問題がある 听り問題がある

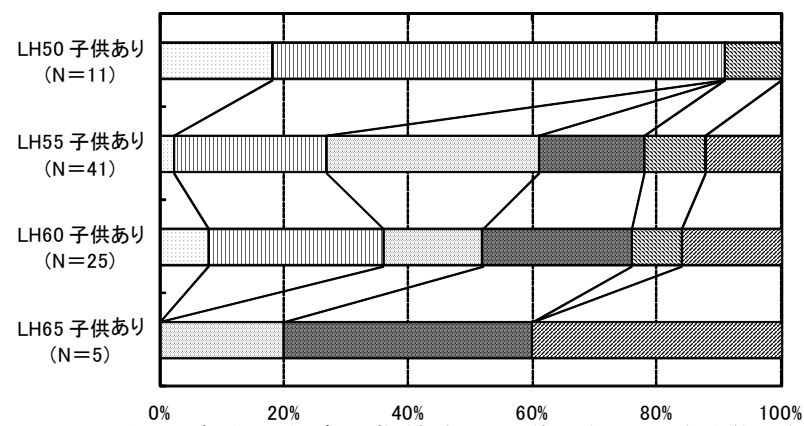

図 22 問題意識の程度の指摘率：上階子供あり(性能別)

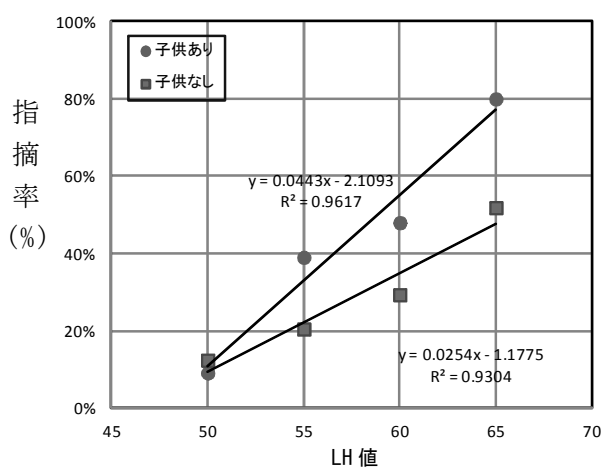

図 23 問題意識の程度の指摘率：上階子供の有無別 (性能別)

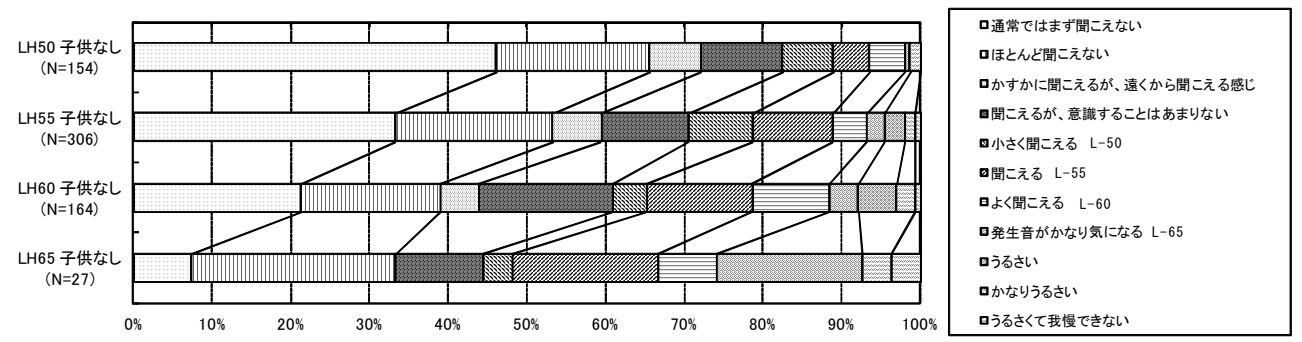

図 24 建築学会基準表現に対する指摘率：上階子供なし( 性能別)

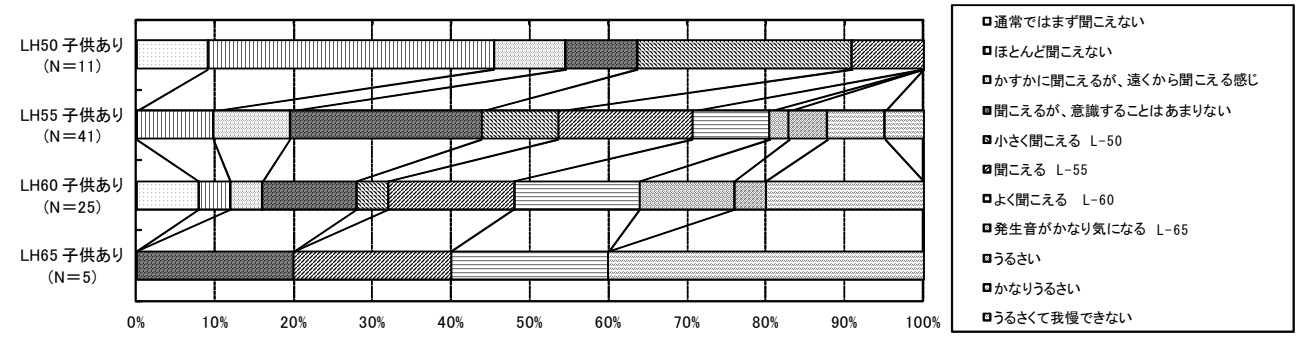

図 25 建築学会基準表現に対する指摘率：上階子供あり(性能別) 
した。これらの割合を直接示したのは、例え ば、ある性能の集合住宅に居住していて、特 定の音を問題視する人の割合がどの程度なの かを知ることにより、消費者が自ら判断する ことを狙ったものである。このような手法は、 音は感覚的なものであることを消費者自ら判 断できる環境を整えていく必要性を感じてい るからである。現在、音環境を説明する際に 利用されている「表示尺度と住宅における生 活実感との対応例」11)では、「LH45：聞こえる が、意識することはあまりない、「LH50：小さ く聞こえる」など、1 つの性能を 1 つの言葉で 表現している。しかし、実際の居住環境では 聞く側の個人差もあり、性能を 1 つの代表する言葉のみで表現する よりも、1 つの性能を様々な角度から説明する方が適確かつ有効な 場合もあると考える。実際の状態を知り得ない状況下において、こ の種の表現は非常に有効であると考える。特に音響性能のような感 覚的問題に依存する傾向が強い場合は有効であろう。

3 ) 子供が上階に居住した場合の反応について言及 :

上階の家族構成・子供の有無により生活実感に変化がみられること から、上階に子供が居住した場合には性能によってより低い等級の 生活実感と同等になることがある事を追記した。また、重量床衝撃 音遮断性能が高くなればその差は小さくなり、性能が低くなればそ の差が大きくなる可能性があることも付加した。なお、図 -20 や図 23 の結果を付加し、より具体的に表現する方法も良いと思われる。 今後 LH 50 など性能の高い物件が増えてくれば、表 1 の結果をより具 体的に検証して行けると考える。

また今回の対応表には記載していないが、紛争トラブルの未然防 止のために問題意識を感じる程度についても何らかの形で表示して いくことが必要であると考える。問題意識の程度については、一般 に表示する事がトラブルを招きかねないとの指摘もあるが、居住後 のトラブルを事前に防ぐためにも、何らかの形で公開していくべき データであると考える。特に、騒音トラブルは被害者となるだけで なく、知らない間に加害者となることもあることから、本データを 公開する事により注意喚起を促すことも可能になると思われる。

\section{4. まとめ}

本研究によって、各等級に対する「聞こえる程度一気になる程度 一うるささの程度一問題意識の程度一満足度の程度」について指摘 率の分布が示された。

また、 $\mathrm{L}$ 等級による評価と長期生活者に対する居住者反応の対応 性が非常に良いことを確認した。さらに、現在広く社会に利用され ている学会の「表示尺度と住宅における生活実感との対応の例」11)が 居住反応と対応が概称取れていることを明らかにした。そのため、 全く新しい対応例を一から示すよりも、社会的混乱を防ぐ意味でも 現在の対応例の一部変更を行う方法が妥当であると判断される。

また、今回検討した「聞こえる音の指摘率」については、今後ラ ウドネスをベースとした実験室実験のデータと組み合わせていく事 により、より適格な性能表現方法となっていくものと考える。実 験室実験では、「聞こえる一聞こえない」など、対象音に焦点を当
て聴取状態にある被験者を対象としており、発生音の程度( 上階住戸 の状況）までは十分考慮されているとは言い難い状況下で実施される ことが多いが、実験室実験により蓄積されている数多くのデータを ベースとして、本研究成果との対応性を検討していくことで、長 期間生活する居住者反応に近い指標を完成させることができると思 われる。

研究成果の具体的提案を表 1 に示したが、これは重量床衝撃音遮 断性能を説明したものであり、複数の説明方法を導入している。こ れは生活実感による表現方法の場合、生活実感は居住者平均として 示し、評価の巾を持って反応変化を示しておく方法が良く、性能 ンクは消費者自ら判断できる方法とすべきであり、自分で選択でき る方法を導入しておく方が良いと考える。

ただし、この結果は、所謂「普通の生活を行っている場合に対す る反応」であり、上下階や左右の住戸間において騒音問題が発生し た場合や聴取状態にある人の反応に対応するものではない。

\section{謝辞}

調查の実施・分析にご協力頂いた、日本大学井上研究室平成 19 年 度修士論文生の大室諒知君、平成 15 年度〜平成 19 年度に本テーマに ついて卒業論文で取り組んだ性能表示班の諸君、並びに、各物件の 管理組合や居住者の方々に心より厚く御礼申しあげ、ここに感謝の 意を表します。

\section{参考文献}

1）日本建築学会編 : 建築物の遮音性能基淮と設計指針(第一版)、技報堂出版、1979.12

2）阿部今日子、井上勝夫 : 住宅性能表示制度と集合住宅の音環境に関寸る居住者 . 供給者の意識調査、日本建築学会技術報告集、第 27 号、pp. $173-178 、 2008.6$

3）光田泰子、木村翔: 集合住宅における生活騒音の実態と T N E L による評価、日 本建築学会論文報告集、第 272 号、pp. $75-86 、 1978.10$

4）光田泰子、木村翔 : 集合住宅における床衝撃音の評価に関する研究、日本建築 学会建築環境工学論文集、No. 4、pp. $37-42 、 1981.5$

5）木村翔、井上勝夫、荘美知子、藤沢一弘 : 集合住宅の音環境に対する居住者意 識と住まい方に関する研究、日本建築学会計画系論文集、第 466 号、pp. $1 \sim 8$ 、 1994. 12

6）荘美知子、木村翔、梶裕佳子、鈴木久恵 : 集合住宅の音環境に対する居住者意 識の形成に関する研究一自由意見の分析を通して一、日本建築学会計画系論文集、 第 485 号、pp. $1 \sim 8$ 、 1996.7

7）荘美知子、木村翔、鈴木久恵、梶裕佳子 : 集合住宅の住環境全般と音環境に対 する居住者評価の分析、日本建築学会計画系論文集、第 493 号、pp. $9 \sim 15 、 1997.3$

8）荘美知子、木村翔、梶裕佳子 : 集合住宅の音環境に対する居住者意識構造の分 
析、日本建築学会計画系論文集、第506 号、pp. 1 7、1998. 4

9）阿部今日子、井上勝夫 : 音環境に関する集合住宅購入時の消費者要求と住宅供 給者の説明、日本建築学会環境系論文集、第. 595 号、pp. 9 ～16、2005. 9

10）阿部今日子、井上勝夫 : 集合住宅の音環境に対する居住者の生活実感と住まい 方に関する研究、日本建築学会環境系論文集、第. 640 号、pp. $667 \sim 673 、 2009.6$

11）日本建築学会編 : 建築物の遮音性能基準と設計指針(第二版)、技報堂出版、 1997. 12

12）国土交通省 : 建築着工統計調查、2003. 4

13）日本建築学会編 : 建物の床衝撃音防止設計、技報堂出版、2009.11

14）阿部今日子、井上勝夫他：音環境に関する居住者反応と性能表現法その 9 住宅 購入時の消費者要求と住宅性能表示制度、日本建築学会大会学術講演梗概集、D1 分冊、pp. $45-46 、 2003.9$

(2013年11月 9 日原稿受理, 2014年 4 月 4 日採用決定） 